\title{
Exploring Determinants of Life Sciences Spin-off Creation: Empirical Evidence from the Netherlands
}

\author{
Paper submitted to \\ International Journal of Entrepreneurship and Small Business
}

May 2008

\author{
Marianne van der Steen \\ Centre for Higher Education Policy Studies (CHEPS) \\ Universiteit Twente \\ Postbus 217, 7500 AE, Enschede, The Netherlands \\ E-mail: m.vandersteen@utwente.nl, Phone: (+31) (0) 534893263, Fax: (+31).... \\ Roland Ortt \\ Delft University of technology, \\ Faculty of Technology, Policy and Management \\ Department of Technology, Strategy and Entrepreneurship, \\ Jaffalaan 5, 2628BX, Delft, The Netherlands \\ E-mail: J.R.Ortt@tbm.tudelft.nl, Phone: (+31) (0)15 27 84815, Fax: (+31) 152784811 \\ Victor Scholten \\ Delft University of technology, \\ Faculty of Technology, Policy and Management \\ Department of Technology, Strategy and Entrepreneurship, \\ Jaffalaan 5, 2628BX, Delft, The Netherlands \\ E-mail: V.E.Scholten@tudelft.nl, Phone: (+31) (0)15 27 89596, Fax: (+31) 152784811
}

Key-words: Academic Spin-offs, Life Sciences, Spin-off Creation Process

We thank the National Research Council (Biopartner and ZonMW) and the Ministry of Economic Affairs to make this research possible. We also like to express our gratitude towards Arthur Tolsma and Koenraad Wiedhaup for their contribution to an earlier version of this document. 


\title{
Exploring Determinants of Life Sciences Spin-off Creation: Empirical Evidence from the Netherlands
}

\begin{abstract}
This paper empirically explores the determinants that are important for the creation of science-based spin-offs. We propose a model in which human capital, technology-based and institutional determinants affect the spin-off creation process. The data are drawn from the BioPartner First Stage Grant, a seed fund to stimulate academic spin-offs in the Life Sciences. The unique data set covers 68 Life Sciences spin-off projects. This study explores the determinants of success of these spin-offs in three subsequent stages of the spin-off creation process and for the overall process. Empirical evidence shows that an externally attracted CEO positively influences the spin-off creation and leverages the effect of the spin-offs scientific quality. Furthermore, we find evidence for the role of product potential, IP position and industry experience which vary during the spin-off creation process. Finally, we discuss managerial and policy implications.
\end{abstract}

Key-words: Academic Spin-offs, Life Sciences, Spin-off Creation Process 


\section{Introduction}

Academic spin-offs have become increasingly important for governments and university administrators worldwide as they are perceived as the engine of economic development, job creation and technological development. Consequently, most governments and universities nowadays have entrepreneurship programs to stimulate spin-offs. Yet, the determinants that lead to the success of spin-offs in their embryonic stages, i.e. before a company is actually founded, remain largely unspecified. A rich amount of literature analyzed the creation process (Di Gregorio and Shane 2003; Link and Scott 2006; Lockett et al 2005; Mustar 2006), the role of intellectual properties (Bekkers et al 2006), the effect of organizational endowments (Shane and Stuart 2002; Landry et al 2006), and the effect of university capabilities (Owen-Smith and Powell 2003) on spin-off performance. Others have provided a useful conceptual framework to understand academic spin-off creation (Vohora et al 2004) and analyzed the process in a broader perspective of knowledge transfer mechanisms (Feldman et al 2006).

However, most contributions in the current literature take a static view in analyzing the role of specific determinants of spin-off creation and its performance, or the role of indirect incentives in the institutional environment (e.g. the Bayh-Dole Act, university policies) in encouraging scientists to consider spin-off creation. Few empirical studies have investigated the dynamics of the success factors during the embryonic stages of academic spin-offs. It makes sense to assume that the role and impact of success factors alter over time depending on the stages of the development of the inventor/business team. This paper focuses on the dynamic and changing character of the spin-off creation process and aims to increase our understanding about the role of determinants during the various stages of spin-off creation.

The article focuses on academic spin-offs in the Life Sciences. These spin-offs are particularly valuable because the commercialization of academic Life Science research is deeply intertwined with the biotechnology sector (Ebers and Powell 2007; Cook-Deegan 2006; Owen-Smith and Powell 2003; Stuart et al 2007). We draw our data from a unique database of 68 academic spin-offs in the Life Sciences. All spin-offs are funded by the BioPartner First Stage Grant, an academic spin-off stimulating program initiated by the Ministry of Economic Affairs in the Netherlands. The Biopartner selection committee provides us with detailed data of these 68 spin-off teams. This committee decides whether a potential spin-off team receives funding for the next phase or not. The structured data collection allows us to conduct statistical analysis. The results of the analysis are discussed in the light of the existing literature.

This paper is structured as follows. Section 2 discusses the role of academic spin-offs in the Life Sciences and the role of the Biopartner program in stimulating them. Section 3 focuses on the spin-off creation process, spin-off success and its determinants. The Biopartner sample is described in Section 4 along with the measurement of success and its determinants. Section 5 provides the data analyses, conclusions and discussions are presented in Section 6.

\section{$2 \quad$ Life Sciences spin-offs}

\subsection{Life Sciences and academic spin-offs in general}

More than in any other field, academic spin-offs in the Life Sciences have moved to the centre of attention of policymakers, university administrators and the management of large companies. There are two parallel explanations. Firstly, the process of drug discovery has change dramatically. Since 2002, small life sciences companies have become the major 
source of FDA approved drugs based on molecular entities (FIGON 2007; Wong 2007). Herewith, the large pharmaceutical companies acquire a different role in the development of new medicins. Secondly, in the past decades, universities have become more active in patenting and commercializing of their scientific discoveries, in particular in the biotechnology related disciplines (Kneller 2007; Meyer 2006).

Therefore, it is not surprising that especially in Life Sciences, a high level of connectivity exists between universities and biotechnology companies (Zucker et al 2002; Stuart et al 2007). There are close and both formal and informal relations between universities and biotechnology firms, for instance in terms of co-authorships between university and R\&D researchers (Owen-Smith and Powell 2001; Gittelman and Kogut 2003) and combined university and firm appointments. According to Stuart et al (2007), half of all biotechnology firms have been founded by university scientists. Many of these scientists maintained academic appointments after the spin-off creation, which is an example of the close relations.

There is, however, a large distance between the university lab and the actual drug development process of pharmaceutical companies. Pharmaceutical companies devote most of their resources to financing clinical trials and the sales and marketing of drugs, whereas universities are engaged in basic biotechnology research of disease processes. Biotechnology academic spin-offs interconnect the two and serve as intermediaries between the university and biotechnology firms (Cook-Deegan 2006) and thereby bring together disparate pieces of knowledge (Burt 2004). The scientific knowledge of a biotechnology academic spin-off company is most often protected by intellectual property rights that is either licensed or transferred to the firm. The firm develops this knowledge further often with various business partners and they are therefore sometimes referred to as "value-added intermediaries" (Stuart et al 2007). Accordingly, academic spin-off serve as a bridge between the public and private sectors. During the early development of the spin-off, the start-up team conducts additional research and development to commercialize the scientific invention and at the same time they have to transform themselves from (star-) scientists into academic entrepreneurs.

\subsection{Life sciences and spin-offs in the Netherlands}

In the Netherlands, eleven universities with biotechnology related departments serve as a knowledge base for the spin-off companies. The disciplinary subfields of the Life Sciences are in particular molecular biology, genomics and combinatorial chemistry. The Dutch government has identified Life Sciences as a priority sector. Consequently, many policy initiatives and programs have been established to stimulate innovation and new start-up companies in these fields. Already in the mid 90s the STIGON program was started to stimulate life science spin-off creation, followed by the Biopartner program in the later 90s. The spin-offs that were initiated during the Biopartner program are analyzed in this study.

\section{$3 \quad$ Spin-off creation, success and its determinants}

\subsection{Spin-off creation}

Along the lines of the Biopartner database, we define an academic spin-off company as a new firm based on innovative technological knowledge that is recently developed at a university. In this paper, we consider the creation of a spin-off company as a process rather than an event (Shane 2004; Landry et al 2006). Based on Vohora et al (2004), we distinguish five phases in the spin-off creation process. In phase 1, a project plan is formed that is based on a scientifically viable invention with a potential to be commercialized. Phase 2 results in a 
business plan. Phase 3 covers the period from the business plan to the launch of a spin-off firm. Phase 4 ends when the spin-off firm acquires follow-up investments. In reality, the spinoff creation process is not a linear process with well-defined phases. For instance, the business model and company focus are often adapted to competing products, to the result of patent applications or are influenced by the FDA (US Food and Drug Administration) approval track. Because of the iterative and dynamic nature of our process approach of spinoff creation, we can analyze the spin-off success in subsequent stages.

\subsection{Spin-off success and its determinants}

Following our dynamic orientation, we define success in terms of important milestones in the spin-off creation process. These milestones are: (1) The provision of finance to work out a businessplan; (2) The financing of funds to establish a company; and (3) The follow-up financing. The milestones reflect important decisions in the new firm creation process (Shane 2003; Vohora et al 2004). Consequently, we focus on the determinants that influence the success of university spin-offs to fulfill the milestone and proceeed to the next phase of spinoff creation. These factors are shown in Figure 2.

Insert Figure 1

About here

\section{Life sciences sector}

Life Sciences is a large and heterogeneous industry comprising multiple (sub) sectors. Different approaches can be adopted to distinguish sectors. In this research we focus on the application of the knowledge, and distinguish 1) the food sector, 2) the medical sector and 3) other general applications.

\section{Public Research Organization Support}

Public research organizations can differ considerably in their policies and facilities for spinoff support (O'Shea et al. 2005). For instance, the university policies regarding the transfer of university patents, and related policies for licenses and royalties (Bekkers et al 2006) and facilities that may support spin-off initiatives such as Technology Transfer Offices, special programs and investment funds (Carayol and Matt 2004; Locket et al 2005; Feldman et al 2002; DiGregorio and Shane 2003; Shane 2004).

\section{Scientific quality of the inventor team}

Several studies conclude that the research reputation of the university is strongly associated with spin-off establishment (DiGregorio and Shane 2003; Feldman et al 2002; Smith et al 2006). Similarly, we focus on the scientific quality of the spin-off team. It is well recognized that scientists play a critical role in the creation of an academic spin-off (Zucker et al 1997, Shane 2004; Murray 2004; Shane and Stuart 2002). Their scientific capacity is a determining factor for start-up creation and their eventual success (Owen-Smith and Powell 2003).

\section{Technology}

Technological strength of the invention is perceived as an important factor in spin-off creation. We measure the technological strength based on the innovativeness of the technology and the scientific embeddedness and quality of the research group where the technology was initially developed. The newness and scientific embeddedness corresponds 
with earlier measures that gauge the technological strength of companies (Koenig 1983; Narin et al 1987).

\section{IP position}

The strength of the intellectual property position is an essential resource for new firms because other resources are often absent (Shane and Stuart 2002). Shane and Stuart (2002) demonstrate that the strength of the patent stock of the start-up firm at the time of founding, is related to a higher likelihood that the firm will be successful later on. We measure IP position by the extent the spin-off team conducted a clear patent analysis and by the IP-position itself.

\section{Product potential}

Product potential is a composite variable that refers to aspects such as the relative advantage of the product compared to competitive products (Ostlund 1974; Tornatzky and Klein 1982) and the clear market positioning of the product vis-à-vis the same competitive products (McKenna 1985). The product potential is furthermore reflected in the number of potential customers for the product and in the anticipated financial results of the product sales (Urban and Hauser 1993).

\section{Development strategy}

Strategies by small companies can emerge step by step or can be explicitly formulated in a plan at one point in time. Deliberate strategies refer to explicitly formulated comprehensive plans, whereas emergent strategies refer to taking one step at a time (Mintzberg and Waters 1985). In the evaluation of the spin-off initiatives the focus was on deliberately chosen strategies.

\section{Entrepreneurial experience}

Companies founded by scientists with previous start-up experience will perform better than first-time entrepreneurs (Vohora et al. 2004). Start-up experience enhances entrepreneurs' understanding of how to staff and manage relationships with investors, employees, suppliers and customers (Brüderl et al 1992; Shane and Stuart 2002).

\section{Industrial experience}

The literature acknowledges that spin-off founders with experience in the industry of the startup are likely to perform better than founders lacking that experience (Bekkers et al. 2006; Landry et al. 2006).

\section{External CEO}

We define an external CEO following the concept of surrogate entrepreneurship (Radosevich 1995) in which non-employee entrepreneurs collaborate with scientists in order to identify and pursue business opportunities grounded in innovative propriety technology.

\section{$4 \quad$ Methods}

\subsection{Biopartner sample}

BioPartner is a Dutch public program that stimulates the creation of academic spinoffs in the Life Sciences. In the period from 2000 to 2007, 71 Dutch academic research teams in the Life Sciences received initial funding from this organization to start a spin-off. The sample contains initiatives in the Life Sciences from different sectors and from different 
universities. Most of the initiatives are from the "human health" sector (40 cases) other initiatives are from the "agro-food" sector (9 cases) and some are from the "general biotechnology"sector (19 cases). The Wageningen University, The University of Utrecht and The Leiden University host most of the spin-off initiatives. The diversity in spin-offs, technologies and universities ensure the heterogeneity of the sample.

During the evaluation and funding procedure, the number of spin-off initiatives decreases. Out of the 133 project plans that were initially submitted, 71 were evaluated favorably by the committee and received initial funding to make a business plan. From the 71 cases, data from three cases were incomplete, leaving a sample of 68 complete cases. Out of these 68 cases, 53 completed a business plan, 39 actually founded a company and 28 received additional funding.

Insert Table 1

About here

\subsection{Comparing Biopartner data with regular spin-off data sources}

To evaluate the spin-off initiatives, Biopartner gathered data about the spin-off from multiple sources such as questionnaires, market reports and experts. This protocol has some important advantages compared to self-completed questionnaires by spin-off entrepreneurs.

The main advantage of the Biopartner protocol is the relative objectivity of the committee evaluation. In contrast, the self-completed questionnaire is a subjective source of data due to the entrepreneurs involvement, experience and expertise which may create a bias (Celsi and Olson 1988). A minimum level of involvement is required in order to be motivated to complete questionnaires, yet a too high a level of involvement may decrease the validity of the results. The validity, expertise and experience are shown to have an inversed U-shaped relationship with the validity of the evaluations in consumer research (Alba \& Hutchinson, 1987). Finally, research in the same field also indicated that respondents are better able to evaluate alternatives in comparison rather than evaluate one alternative in a monadic way (Finn 1985; Moore 1982).

The Biopartner protocol involved multiple experts to evaluate spin-off initiatives. These experts were not associated with the initiative (so the bias was avoided) yet they had sufficient experience and expertise in the field of Life sciences to understand and therefore validly evaluate the initiatives. In order to further increase the validity of their evaluations, they used standard forms to evaluate the initiatives in a similar way and they discussed the initiatives with the other experts. Most important, however, they were able to compare many of these initiatives and therefore rate the alternatives more careful. Table 2 compares the mainstream approach with the Biopartner protocol.

Insert Table 2

About here 


\subsection{Data collection and measurement}

There are four sources of data. First, the spin-off proposal was thoroughly examined by the experts in the Advisory Committee for its commercial potential. Each expert individually completed a questionnaire with 25 items that addressed commercial, scientific as well as general aspects of the proposal. The project proposals represent a second source because they contained valuable information regarding team qualities and experience. As a third source, the ISI web-based citation index was consulted to assess the scientific quality of the research group where the spin-off inititiave emerged from. The fourth source of data is the final report and oral project evaluation by the Advisory Committee. The combination of four sources yields thirty items per proposal. These items are coded and further condensed into a limited number of variables covering four success measures and ten determinants of success.

\section{Success measure}

We have defined success in terms of the achievement of milestones relevant in this phase of spin-off creation. In our data set, this is measured in two ways. First, the success is measured by the factual achieved milestones: completion of a business plan, foundation of a company and reception of follow-up financing. Each milestone is a dichotomous item (yes=1 and no=0). Also an overall success measure, based on the summation of these items (values between 0-3), was used. Second, we measured success by the project evaluations and reports that were used to assess whether the spin-off inititative obtained funding. This subjective evaluation by the Advisory Committee is measured on a Likert scale (a scale ranging from 'very low anticipated success' to 'very high anticipated success'). A value ' 0 ' was given to 'very low anticipated success' values 1 to 4 were given to the other categories. The two success measures are combined to construct a success index (with the values 0-7). The success index reflects both objective and subjective considerations, see Table 3.

Insert Table 3

About here

In this way we can assess both the overall success of the spin-off initiative (using the success index) and the success at various phases of the spin-off creation process (using the completion of the milestones).

\section{Determinants of success}

The measurement of the determinants of success is shown in Table 4. The items are listed in the third column and the scales used are in the fourth column. The Life Sciences sector, entrepreneurial experience, industrial experience and external CEO attracted are measured on a nominal scale. The remaining determinants, PRO support, scientific quality, IP position, technology, product potential, and development strategy are measured by multiple items based on likert-scales. Reliability analysis shows good results for the scales (reliability $>0.7$ ).

Insert Table 4

About here 


\section{$5 \quad$ Results}

\subsection{Introduction}

The results are divided in three parts. In the first part, we analyse the determinants of overall success using two models: a linear regression model and a multiplicative regression model. The multiplicative model is transformed into a linear model by taking the logarithm of both sides of the equation. The logarithms of the variables are then used as dependent and independent variables in a linear regression analysis:

$$
\log \mathrm{Y}=\log \mathrm{C}_{0}+\mathrm{C}_{1} \log \mathrm{X}_{1}+. .+\mathrm{C}_{10} \log \mathrm{X}_{10}
$$

Next we analyse in the second part the role of the determinants of success in various phases of the spin-off creation process. We use the success measure of achieving milestones which is based on a dichotomous variable, therefore we use binary logit regression analysis. The logit model uses the independent variables to estimate the chance that a spin-off initiative will pass a specific phase of the spin-off creation process. Rather than directly relating the independent variables to this chance $\mathrm{P}$ a transformed value of this chance is used as dependent variable:

In the third part of the analysis we elaborate on some of the findings from part 1 and 2. In doing so, we investigate the interaction of some of the most important independent variables in their effect on overall success of spin-off initiatives. We use analysis of variance to assess the effect of two factors and their interaction on overall success.

\subsection{Results Part 1: determinants of overall success}

In this part a linear regression equation is formed with overall success as dependent and the ten variables from Table 5 as independent variables. Because of the limited sample size $(n=68)$ compared to the number of variables, we use a stepwise regression procedure. The result of this procedure leads to one factor: the external CEO (Table 5).

Insert Table 5

About here

In order to check the result from the linear regression model and in order to allow interaction we also formed a multiplicative model that is transformed into a linear equation that can be estimated using linear regression (see Part 1 in Section 5.2). We used a stepwise regression procedure. The result of this analysis is in Table 6. The first rows show that External CEO and IP position are important determinants of overall success. These results confirm the importance of the CEO from the previous analysis.

Insert Table 6

About here

It becomes clear that the success factor 'External CEO' is the most important success factor for overall success. Using a t-test we analysed whether success for both groups (with and 
without an External CEO) differs significantly. The results show that indeed the involvement of an External CEO significantly influences the spin-off success.

Insert Table 7

About here

\subsection{Results Part 2: determinants of success at various phases of the process}

In Table 8 we provide the analyses for spin-off success at various phases of the process. The Beta (and p-value) for the variables that have a significant influence on success are shown. The first stage is the completion of a business plan and is shown in the second column of Table 8. The second stage is the formal formation of a spin-off, which is shown in the third column. The third stage is the follow-up financing (see fourth column). Because of the limited sample size, we used a stepwise procedure.

Insert Table 8

About here

The table shows that for the first two stages (completion of business plan and formally establishing a company) both the external CEO and the Industrial Experience have a significant relationship with success. Contrary to the expectations, however, Industrial Experience seems to have a negative effect on success in the first two stages. Succes in the last stage (follow-up financing) is positively affected by the availability of an external CEO, industrial experience and IP-position. Contrary to the expectations, however, Product potential seems to have a negative relationship with success.

\subsection{Results Part 3: interaction effects}

The previous analyses indicate the paramount importance of the external CEO for the success of the spin-off initiative. It is remarkable that, even for a fundamentally science-based sector like the Life Sciences, no relationship appears between the scientific quality of the proposals and the later success. This may be due to the sampling of the scientifically most promising initiatives by the committee. The selection procedure may have excluded proposal with low scientific relevance. Scientific quality, however, still shows considerable variance and as a result we investigated whether this variable was related to other independent variables.

We found an interesting interaction effect between scientific quality of the team members and the availability of an external CEO. We transformed the scientific quality into an ordinal scale that distinguishes high and low scientific quality. High refers to the cases with the top $40 \%$ scientific quality, low refers to cases with the lowest $40 \%$ scientific quality. In order to distinguish the low from the high group, the middle group of about $20 \%$ was removed from the sample. The availability of an external CEO is already measured as a dichotomous variable. Table 9 shows the mean overall success scores for combinations of low/high scientific quality and the availability of an external CEO. 
Insert Table 9

About here

The results in the second row show that for the 34 initiatives without an external CEO, the average overall success decreases from 3.58 to 2.53 when the scientific quality changes from low to high. However, for the 17 initiatives with an external CEO the average overall success increases from 4.17 to 6.36 when scientific quality increases. The results show a significant effect for the external CEO $(F=51.79 ; p=0.005)$ and for the interaction between the external CEO and scientific quality $(F=4.72 ; p=0.035)$. The lack of a significant effect from scientific quality on success confirms earlier results. This implies that the external CEO somehow enables to leverage the effect of scientific quality.

\section{Discussion and Conclusions}

This paper extends the research conducted by Landry et al (2006) by proposing a fully quantitative empirical overview of the determinants of success during various stages of academic spin-off creation. Using a unique dataset from the Biopartner program, we explored the impact of a broad range of factors on the creation process of 68 spin-off initiatives in the Life Sciences. This longitudinal approach allowed us to monitor the altering impact of these factors in subsequent stages of the spin-off creation process. In addition, this paper provides unique insights in the selection process of the Biopartner Advisory Committee. The committee consisted of a team of successful Life Sciences academic entrepreneurs, venture capitalists and industry leaders in the biotechnology sector. Over a period of 7 years, the Biopartner Advisory Committee has built a database of determinants to select spin-offs for funding. Using the data we could analyse the success factors of academic spin-offs and compare them with other studies. The first and most important conclusion is the prominent role of an external CEO in the spin-off creation process. For both models that predict overall success and success during various phases of spin-off creation, we found a positive effect of the external CEO.

\section{Related studies}

Our findings confirm previous research efforts that claim the importance of an external CEO, rather than the inventor scientist as the general manager (Franklin et al 2001). Apparently, the Advisory Committee for investments in life sciences spin-offs is not hindered by a lack of supporting evidence or high levels of uncertainty associated with adopting a surrogate entrepreneur as observed in Franklin's study (2001). In contrast, they are more appreciative if founding teams can benefit from the distinctive qualities that external CEOs bring to the spinoff. Interesting is then the quality that these external CEOs bring to the spin-off team. Similarly it is remarkable that the advisory commission barely approves teams during early phases, such as business plan completion and company founding, that have high levels of industry or entrepreneurial experience. Concurrently, at the phase of follow-up financing industry experience is perceived as a positive team attribute. Regarding the external CEO's contribution to the spin-off, these findings may well indicate that CEOs can help spin-offs by deploying their network contacts and engage in cooperative relationships which are important for the success of entrepreneurial firms (Dowling and Helm, 2006) and essential for the commercial translation of the scientific finding (Liebeskind et al 1996). 
Another interesting finding is that the scientific quality of the spin-off team is neither associated with overall success nor with any success at intermediate phases of the spin-off creation process. This may well correspond with earlier findings by Deeds et al (1999) who found a negative correlation between the number of Ph.D.'s in the management team of a spin-off company and it's success. Also Corolleur et al (2004) indicate that star scientists are involved in more risky firms, which may make the advisory committees more cautious. Similarly, the findings may support the view that if scientists take part in spin-off founding teams, the university will lose valuable scientific staff members or it may invoke conflicting interests (Campbell and Slaughter 1999).

Further examination of the data involves the analysis of interaction effects. One of the most important findings is that the external CEO leverages the effect of scientific quality on spin-off success. A significant positive effect is found between the availability of an external CEO and the scientific quality of the team on the overall success of the spin-off initiative. This interaction effect is visualized in Figure 2 showing that teams with high levels of scientific quality will be more successful in spin-off creation if they attracted an external CEO compared to teams with low levels of scientific quality. At the same time Figure 2 reveals that teams without an external CEO will be more successful if they have little scientific quality in the team. This may indicate that the external CEO is valuable to the commercial articulation of the scientific finding. He may be better equipped to find the right commercial purpose for the spin-off by using his business contacts and complement the scientists' skills with his/her business skills. This finding corresponds with earlier findings based on case studies that indicate that teams should co-evolve and may benefit from combining the relative advantages of both scientists and CEO’s (Clarysse and Moray 2004; Franklin et al 2001).

Insert Figure 2

About here

\section{Policy implications of the findings}

The findings can have a number of policy implications. First, they add to the debate whether to encourage scientists or external entrepreneurs to take the lead in an academic spin-off. Previous studies used mainly case-based studies to address the issue of the role of scientists and external entrepreneurs in the process of the spin-off creation (Clarysse and Morray 2004; Vohora et al 2004; Shane 2000). Second, this study contributes to the debate of the role of scientists and external entrepreneurs to explain the success of the spin-off creation process whereas other studies analyzed their roles in what they bring to the spin-off (Murray et al. 2004) or how it influenced the university attitude (Franklin et al 2001).

So far, the attention in many entrepreneurship policies and program have focused on the availability of venture capital (for spin-off in a later stage of development) or on the other end of the spectrum, incentives for scientists to disclose their inventions and promote commercialization of university knowledge. Though these issues remain important, the role of the external CEO in those early phases of spin-off creation and for the development of business capabilities have been less central at least in the national spin-off programs in the Netherlands and many countries in continental Europe.

Finally, our research demonstrates that a good selection procedure to identify commercially viable scientific findings is just a first step. Moreover, success requires an external CEO to close the business gap. This finding raises new questions such as where to find these CEOs? Are there sufficient (serial) entrepreneurs available in a country or in a 
university environment? Do potentially good projects fail because of a lack of CEOs? These are challenges for policy makers and university administrators in the years to come.

\section{References}

Alba, J.W., and Hutchinson, J.W., 1987. Dimensions of consumer expertise. Journal of Consumer Research, 13, p.411-454.

Bekkers, R., Gilsing, V., and van der Steen, M., 2006. Determining factors of IP-based spin-offs. Journal of Technology Transfer, 31, p.545-566.

Brüderl, J., Preisendörfer P., and Ziegler, R., 1992. Survival changes of newly funded business organizations. American Sociological Review, 57, p.227-242.

Burt, R., 2004. Structural holes and good ideas. American Journal of Sociology, 110,(2), p. 349-399.

Campbell, T.I., and Slaughter, S., 1999. Faculty and administrators' attitudes toward potential conflicts of interest, commitment, and equity in university-industry relationships. Journal of Higher Education, 70, p.309-351.

Carayol, N., and Matt, M., 2004,. The exploitation of complementarities in scientific production process at the laboratory level. Technovation, 24(6), p.455-465.

Celsi, R.L, and Olson, J.C., 1988. The role of involvement in attention and comprehension processes. Journal of Consumer Research, 15 (September), p.210-224.

Clarysse, B., and Moray, N., 2004. A process study of the entrepreneurial team formation: The case of a research based spin-off. Journal of Business Venturing, 19, p.55-80.

Cook-Deegan, R., 2007. The Sciences commons in health research: structure, function and value. Journal of Technology Transfer, 32(3), p.131.

Corolleur, C.D.F., Carrere M., and Mangematin, V., 2004. Turning scientific and technological human capital into economic capital: the experience of biotech start-ups in France. Research Policy, 33 (4), p.631-642.

Deeds, D.L., DeCarolis, D., and Coombs, J., 1999. Dynamic capabilities and new product development in high technology ventures: an empirical analysis of new biotechnology firms. Journal of Business Venturing, 15, p.211-229.

Di Gregerio, D., and Shane, S.A., 2003. Why some universities generate more start-ups than others? Research policy, 32, p.209-227.

Dowling, M., and Helm, R., 2006. Product development success through cooperation: A study of entrepreneurial firms. Technovation, 26(4), p.483-488.

Ebers, M., and Powell, W., 2007. Biotechnology: Its origins, organization and outputs, introduction to the special issue. Research Policy, 36, p.433-437.

Feldman, M., Feller, I., and Berkovitz, J., 2002. Equity and technology transfer strategies at American Research Universities. Management Science, 48(1), p.105-121.

Figon, 2007. Creating new drug companies by empowering academic research. Report and recommendations of the Figon committee on medicines innovation. Draft Report: September 10, 2007.

Finn, A., 1985. A theory of the consumer evaluation process for new product concepts. In: Sheth, J.N. (ed.). Research in Consumer Behavior, (1), p.35-65.

Franklin, S.J., Wright, M., and Lockett, A., 2001. Academic and surrogate entrepreneurs in university spin-out companies. Journal of Technology Transfer, 26, p.127-141.

Gittelman, M., and Kogut, B., 2003. Does good science lead to valuable knowledge; Biotechnology firms and the evolutionary logic of citation patterns. Management Science, 49(4), p.366-382. 
Kneller, R., 2007. The beginning of university entrepreneurship in Japan: TLO and bioventures lead the way. Journal of Technology Transfer, 32, p.435-456.

Koenig, E., 1987. A Bibliometric Analysis of Pharmaceutical Research. Research Policy, 12, p.15-36.

Narin, F., Noma, E., and Perry, R., 1987. Patents as indicators of corporate technological strength. Research Policy, 16(2-4), p.143-155.

Landry, R., Amara, N., and Rherrad, I,.2006. Why are university researchers more likely to create spin-offs than others? Evidence from Canadian universities. Research Policy, 35, p.1599-1615.

Liebeskind, J.P., Oliver, A.L., Zucker, L., and Brewer, M., 1996. Social networks, learning, and flexibility: sourcing scientific knowledge in new biotechnology firms. Organization Science, 7(4), p.428-442.

Link, A., and Scott J., 2005. Opening the ivory tower's door: An analysis of the determinants of the formation of U.S. university spin-off companies. Research Policy, 34(7), p.1106-1112.

Lockett, A., Siegel, D., Wright, M., and Ensley, M., 2005. The creation of spin-of firms at public research institutions: managerial and policy implications. Research Policy, 34, p.981-993.

McKenna, R.,1985. Market Positioning in High Technology. California Management Review, 27(3), p.82-108.

Meyer, M., 2006. Academic inventiveness and entrepreneurship: On the importance of start-up companies in commercializing academic patents. Journal of Technology Transfer, 31, p.501510.

Mintzberg, H., and Waters, J.A., 1985. Of strategies: Deliberate and emergent. Strategic Management Journal, July/ September, p.257-272.

Moore, W.L., 1982. Concept testing. Journal of Business Research, 10(Fall), p.279-294.

Murray, F., 2004. The role of academic inventors in entrepreneurial firms: sharing the laboratory life. Research Policy, 33(4), p.643-659.

Mustar, P., (2006). Spin-off enterprises -How French academics create hi-tech companies: the conditions for success or failure. Science and Public Policy, 21(1), p.110-131.

O'Shea, R., Allen, T., Chevalier, A., and Roche, F., 2005. Entrepreneurial orientation, technology transfer and spin-off performance of U.S. Universities. Research Policy, 34, p.994-1009.

Ostlund, L.E.,1974. Perceived Innovation Attributes as Predictors of Innovativeness. Journal of Consumer Research, 1 (September), p. 23-29.

Owen-Smith, J., and Powell, W., 2003. The Expanding role of university patenting in the life sciences: assessing the importance of experience and connectivity. Research Policy, 32, p.1695-1711.

Radosevich, R., 1995. A model for entrepreneurial spin-offs from public technology sources. International Journal of Technology Management, 10, p.879-893.

Shane, S.A., 2000. Prior knowledge and the discovery of entrepreneurial opportunities. Organization Science, 11(4), p.448-462.

Shane, S.A., 2004. Academic Entrepreneurship, Edward Elgar Publishers: Cheltenham, UK.

Shane, S.A., and Stuart, T., 2002. Organizational endowments and the performance of university startups. Management Science, 48, p.154-170.

Smith, H., and Ho K., 2006. Measuring the performance of Oxford University, Oxford Brookes University and the government laboratories' spin-off companies. Research policy, 35, p.15541568.

Stuart, T., Ozdemir, S.Z., and Ding, W., 2007. Vertical alliance networks: The case of universitybiotechnology-pharmaceutical alliance chains. Research Policy, 36, p.477-498.

Tornatzky, L.G., and Klein, K.J., 1982. Innovation Characteristics and Innovation Adoption-Implementation: A Meta-Analysis of Findings. IEEE Transactions on Engineering Management, 29 (1) (February), p. 28-45.

Urban, G.L., and Hauser, J.R.,1993. Design and Marketing of New Products. Prentice-Hall: London.

Vohora, A., Wright, M., and Lockett, A., (2004). Critical junctures in the development of university high-tech spinout companies. Research Policy, 33, p.147-175.

Wong, P-K., 2007. Commercializing biomedical science in a rapidly changing triple helix nexus: The experience of the national University of Singapore. Journal Technology Transfer, 32, p.367-395.

Zucker, L., Darby, M., and Armstrong, J., 2002. Commercializing knowledge: University science, knowledge capture, and firm performance in biotechnology. Management Science, 48(1), p.138153. 


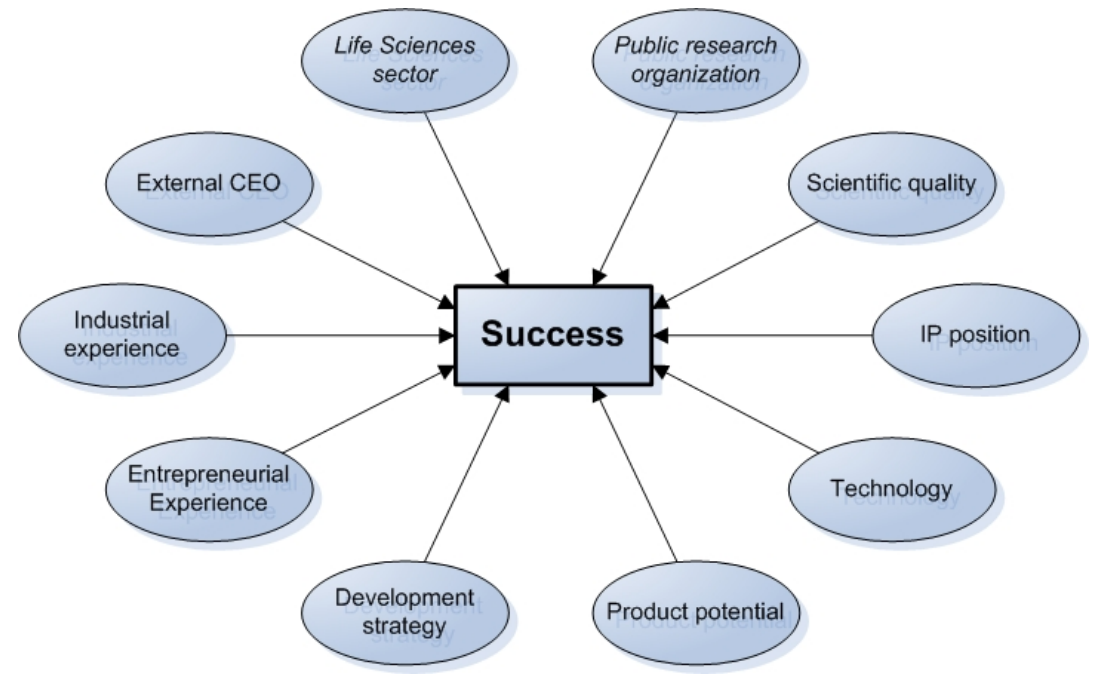

Figure 1 Determinants of science-based spin-off success 
Table 1

The number of initiatives during the process

\begin{tabular}{|l|l|}
\hline Phase & No of initiatives \\
\hline 1. Submission of a project plan & 133 \\
\hline 2. Selection of plans that receive initial funding & 71 \\
\hline 3. Completion of Business plan & 53 \\
\hline 4. Foundation of company & 39 \\
\hline 5. Follow-up funding & 28 \\
\hline
\end{tabular}

Table 2 Comparison between mainstream and Biopartner data.

\begin{tabular}{|l|l|}
\hline Mainstream data & Biopartner data \\
\hline Self-completed survey & Data from experts after discussions \\
\hline $\begin{array}{l}\text { Main actor/individual involved in spin-off completes } \\
\text { the questionnaire }\end{array}$ & Experts not involved in spin-off \\
\hline One case & Many cases \\
\hline Cross sectional data & Longitudinal data \\
\hline
\end{tabular}

Table $3 \quad$ Measuring success

Measuring success:

Facts: Achievement of milestones

- Business Plan? (0/1)

- Company founded? (0/1) $\}$ Success measure $1(0-3)$

- Follow-up financing?

$(0 / 1)$

Success index (0-7)

Evaluation: Assessment by committee

- Successful? (0-4) Success measure $2(0-4)$

Pearsons correlation between success measure 1 and 2 (0.825; Significance: $p=0.000)$ 
Table 4 Measuring the determinants of success

\begin{tabular}{|l|l|l|l|l|}
\hline $\mathbf{N r}$ & Variable & Items & Scale & Scale reliability \\
\hline 1 & Life Science sector & Agro-food, Human health or General & Nominal & - \\
\hline 2 & PRO support & $\begin{array}{l}\text { assistance from the PRO? } \\
\text { acceptable PRO agreement? } \\
\text { IP transfer from PRO? }\end{array}$ & Interval & .708 \\
\hline 3 & Scientific quality & $\begin{array}{l}\text { Scientific rank } \\
\text { Citation analysis: H-index } \\
\text { Citation analysis: \# citations }\end{array}$ & $\begin{array}{l}\text { Ordinal } \\
\text { \& Interval }\end{array}$ & .862 \\
\hline 4 & IP position & $\begin{array}{l}\text { clear IP position analysis? } \\
\text { IP position promising? }\end{array}$ & Interval & .868 \\
\hline 5 & Technology & $\begin{array}{l}\text { innovative technology? } \\
\text { sound scientific basis of project? } \\
\text { state of the art technology? } \\
\text { quality research group? } \\
\text { technology promising? }\end{array}$ & Interval & .739 \\
\hline 6 & Product potential & $\begin{array}{l}\text { realistic market potential analysis? } \\
\text { market position promising? } \\
\text { realistic commercial analysis? } \\
\text { realistic competition analysis }\end{array}$ & Interval & .858 \\
\hline 7 & Development strategy & $\begin{array}{l}\text { clear product description? } \\
\text { clear strategy? } \\
\text { realistic strategy? } \\
\text { clear work schedule? } \\
\text { effective work schedule? } \\
\text { realistic work schedule? } \\
\text { realistic cost estimations? }\end{array}$ & Interval & .882 \\
\hline 8 & Entrepreneurial experience & Nominal & - \\
\hline 10 & & Industrial experience & Nominal & - \\
\hline
\end{tabular}

Table 5 Results of linear regression analysis of overall success

\begin{tabular}{|c|c|c|c|}
\hline $\begin{array}{l}\text { Dependent variable: } \\
\text { Overall success }\end{array}$ & Independent variables & Beta & Significance \\
\hline \multirow[t]{2}{*}{ Coefficients: } & (Constant) & & .000 \\
\hline & External CEO & .361 & .002 \\
\hline \multicolumn{4}{|c|}{$\begin{array}{l}\mathrm{R}^{2}=0.131 \\
\mathrm{~F}=9.914 \text { (significance } \mathrm{p}=0.002)\end{array}$} \\
\hline \multirow[t]{9}{*}{ Excluded variables: } & PRO support & -.067 & .566 \\
\hline & Technology & .147 & .215 \\
\hline & IP position & .148 & .201 \\
\hline & Product potential & .016 & .891 \\
\hline & Development strategy & .010 & .928 \\
\hline & Life Science sector & .180 & .543 \\
\hline & Scientific quality & -.127 & .390 \\
\hline & Entrepreneurial experience & .071 & .124 \\
\hline & Industrial experience & .103 & .271 \\
\hline \multicolumn{4}{|l|}{$\begin{array}{l}\mathrm{R}^{2}=0.253 \\
\mathrm{~F}=1.926(\mathrm{p}<0.06)\end{array}$} \\
\hline
\end{tabular}


Table $6 \quad$ Results of multiplicative regression analysis of overall success

\begin{tabular}{|l|l|r|r|}
\hline $\begin{array}{l}\text { Dependent variable } \\
\text { Log Overall success }\end{array}$ & Independent variables & \multicolumn{1}{l|}{ Beta } & Significance \\
\hline Coefficients: & (Constant) & & .000 \\
\cline { 2 - 4 } & Log (External CEO) & .342 & .003 \\
\hline \multicolumn{3}{|l|}{} \\
\hline $\mathrm{R}^{2}=0.189$ \\
$\mathrm{~F}=7.598(\mathrm{p}<0.001)$
\end{tabular}

Table $7 \quad$ Results of the independent samples T-test

\begin{tabular}{|lrll}
\hline \multicolumn{2}{l}{ T-test External CEO vs. success: } & & \\
\hline With external CEO: & N: 24 & Mean 5.21 & Std. Dev. 2.23 \\
Without external CEO: & N: 44 & Mean 3.20 & Std. Dev. 2.65
\end{tabular}

T-value: 3.31. Significance: .002

Table 8 Results of logit regression analysis predicting success at various stages

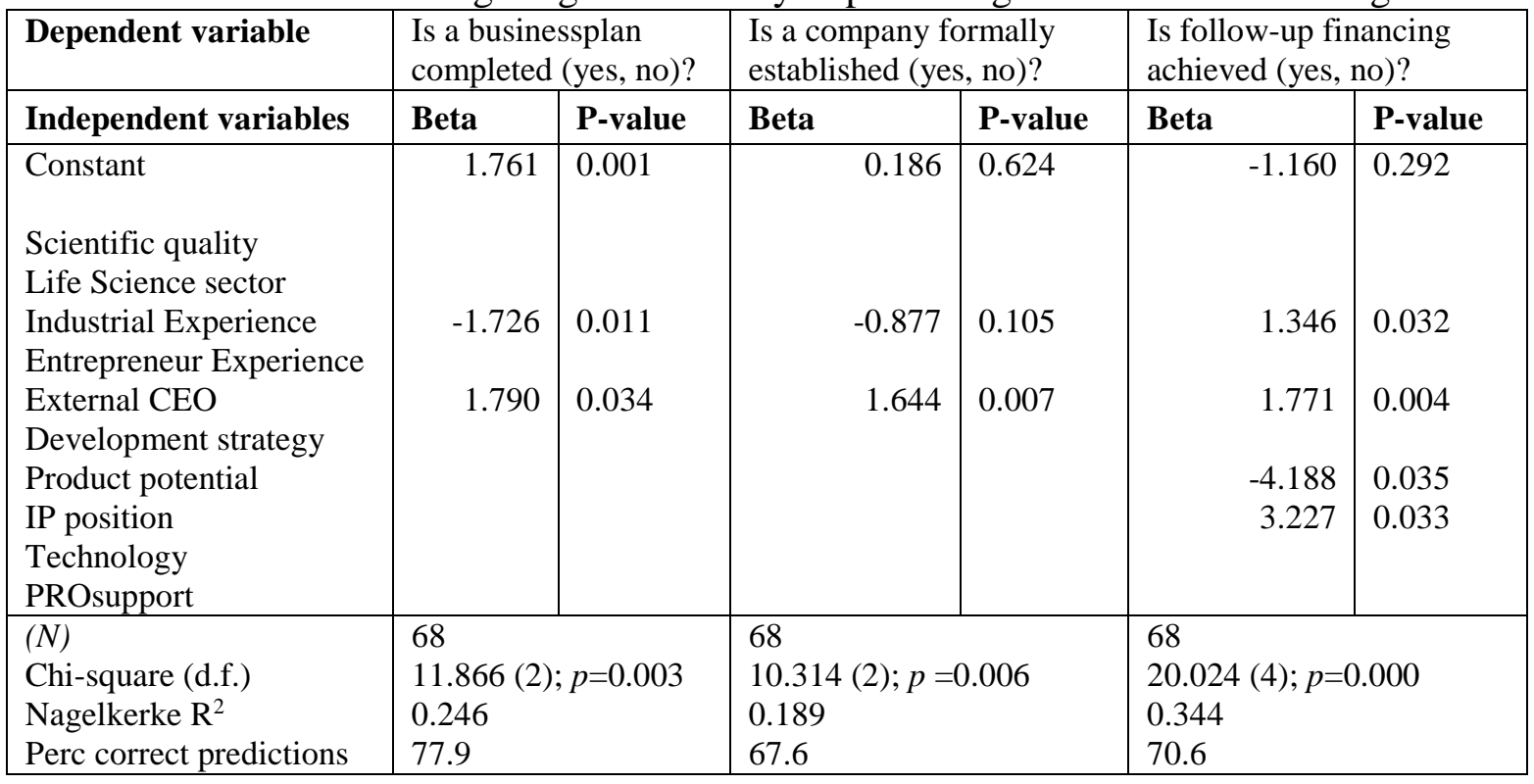


Table 9 Interaction between external CEO and scientific quality on overall success

\begin{tabular}{|l|l|l|l|l|}
\hline External CEO & $\begin{array}{l}\text { Scientific } \\
\text { quality }\end{array}$ & Mean & $\begin{array}{l}\text { Standard } \\
\mathrm{dev}\end{array}$ & $\mathrm{N}$ \\
\hline No & Low & 3.58 & 2.63 & 19 \\
& High & 2.53 & 2.67 & 15 \\
& Total & 3.12 & 2.66 & 34 \\
\hline Yes & Low & 4.17 & 2.56 & 6 \\
& High & 6.36 & 1.43 & 11 \\
& Total & 5.59 & 2.12 & 17 \\
\hline Total & Low & 3.72 & 2.57 & 25 \\
& High & 4.15 & 2.92 & 26 \\
& Total & 3.94 & 2.74 & 51 \\
\hline
\end{tabular}

Figure 2 Interaction effects between External CEO and Scientific Quality of the Team

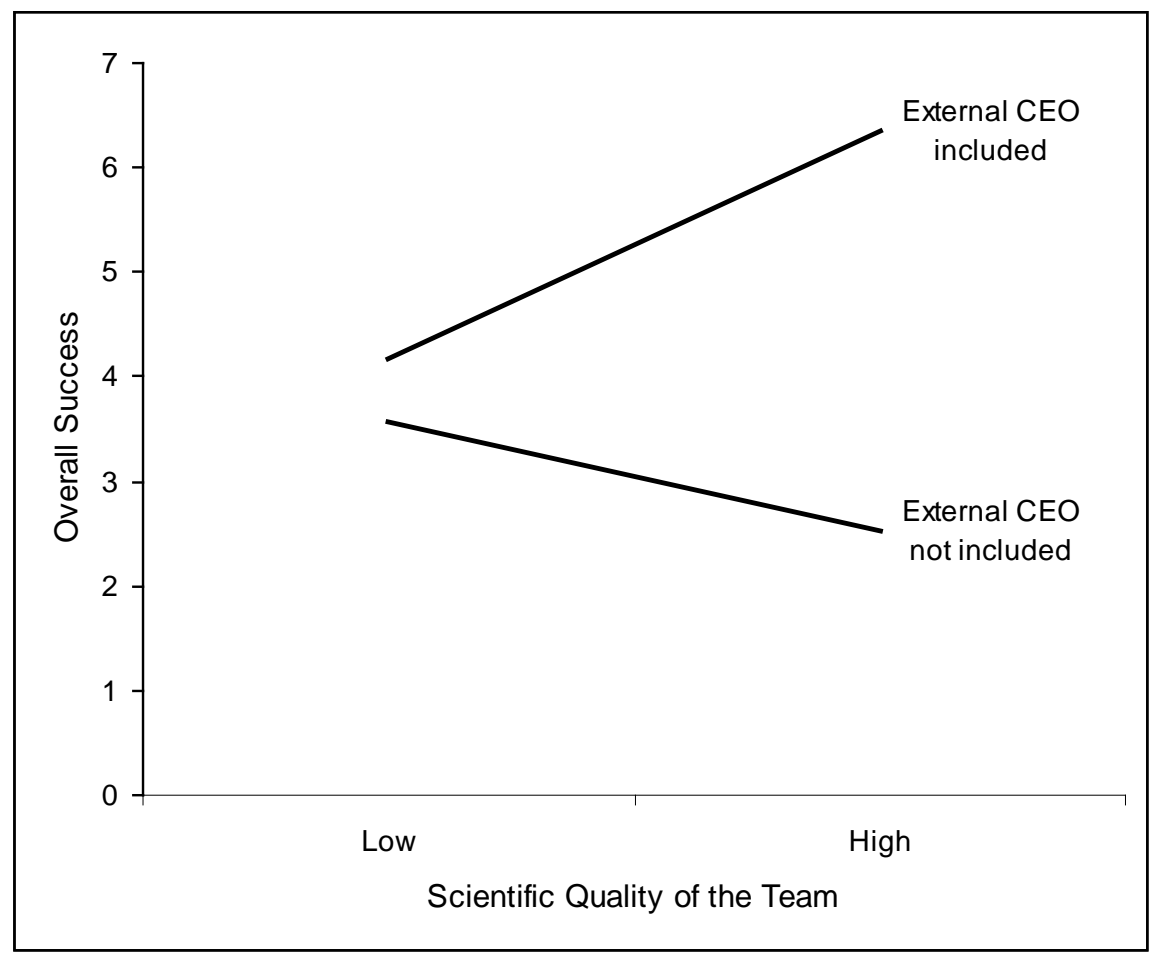

